\title{
Seabirds as a subsistence and cultural resource in two remote Alaskan communities
}

\author{
$\underline{\text { Rebecca C. Young }}^{1}$, Alexander S. Kitaysky ${ }^{1}$, Courtnev Carothers ${ }^{2}$ and $\underline{\text { Ine Dorresteijn }}^{1}$
}

\begin{abstract}
Small rural Alaskan communities face many challenges surrounding rapid social and ecological change. The role of local subsistence resources may change over time because of changes in social perception, economic need, and cultural patterns of use. We look at the Bering Sea's Pribilof Islands, comprising two very small communities, and investigate the relationship between the local residents and seabirds as a natural resource. Seabirds may strengthen ties to older ways of life and have potential for future economic opportunities, or modernization may direct interest away from seabirds as a cultural and economic resource. We conducted a survey and interviews of residents of the two Pribilof Island communities, St. Paul and St. George, to assess opinions toward seabirds and harvest levels. Seabirds were generally regarded as important both to individuals and the wider community. However, current levels of subsistence harvest are low, and few people continue to actively harvest or visit seabird colonies. Respondents expressed desire for greater knowledge about seabirds and also concerns about the current economy of the islands and a lack of future development prospects. Despite the challenging economic conditions, the villages retain a strong sense of community and place value on their environment and on seabirds. Surveys indicated an interest in developing eco-tourism based around local resources, including seabirds, as a way to improve the economy.
\end{abstract}

Key Words: Aleut; Pribilof Islands; seabird; subsistence; survey; tourism

\section{INTRODUCTION}

Small remote communities in the 21 st century face many challenges, especially in the Arctic and subarctic (Dryzek and Young 1985, Chabot 2003, Berman et al. 2004). Social, environmental, and economic systems have all changed because of forces of modernization and globalization. Economic change and development strategies have attempted to draw these communities into the modern world, often with mixed success, and poverty is still common (Berardi 1998). Resource extraction and climate change have damaged local environments in many areas (Hay 2013). More connectedness via increased transportation and exposure to media, along with social and economic transitions, have led to more emigration to population centers and out of the villages, and less engagement in local subsistence practices (Wolfe and Walker 1987, Moerlein and Carothers 2012).

The Pribilof Islands, a pair of remote communities located in the southeastern Bering Sea, have a unique history of forced settlement and sealing industry exploitation (Fig. 1). The Russian fur companies forcibly resettled Aleuts from the Aleutian Islands to the previously uninhabited Pribilofs in the early 19th century (Jones 1980). Aleut culture, which relied on a large variety of subsistence resources, was constrained by the relatively speciespoor Pribilofs, which previously had been used only as hunting grounds (Veltre and Veltre 1981, Corbett and Swibold 2000). The fur seal harvest came to dominate the culture and subsistence harvest of the islands, causing a decline in other forms of subsistence (Scholz et al. 2007). After the purchase of Alaska from Russia in 1867 , life for the people was heavily controlled at every level, including travel and marriage choices for these "wards" of the U.S. government (Corbett and Swibold 2000). The lucrative fur seal harvest repaid Alaska's purchase price to the U. S. government by the early 20th century. The Aleuts of the Pribilofs gained control of the islands and the seal harvest from the U.S. government in 1983. However, international demand for seal pelts had declined and commercial sealing was soon outlawed (Young 1987). The collapse of this industry damaged the Pribilovian economy and contributed to a disconnect between the human communities and the environment. Huntington et al. (2009) found that the people of the Pribilofs were engaged with each other and their landscape and did not move away despite poor economic conditions, declining subsistence, and a changing environment, e.g., snow crab decline. This desire to adapt and remain, in the face of a seemingly low-resilience system, makes the use of subsistence resources particularly interesting in this location. Use of fur seals on the islands has been welldocumented, but literature for other subsistence resources are scarce. To address this deficit, we document the role and use of seabirds as a subsistence resource on the Pribilofs.

Fig. 1. Map of study locations in the Bering Sea. The Pribilof Islands with the communities St. Paul and St. George marked.

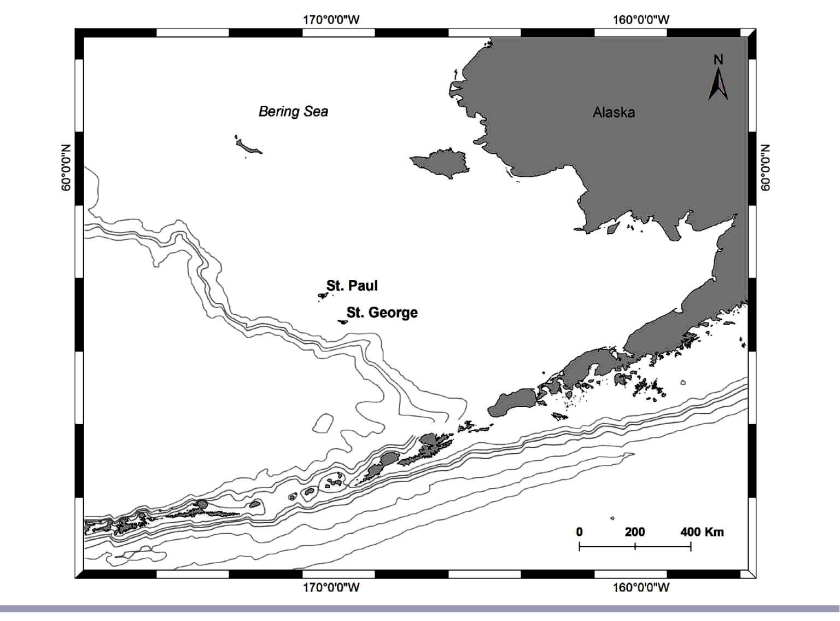

${ }^{1}$ Department of Biology and Wildlife, Institute of Arctic Biology, University of Alaska Fairbanks, ${ }^{2}$ School of Fisheries and Ocean Sciences, University of Alaska Fairbanks 
Many rural communities, especially in Alaska and Canada, rely on mixed economies, which combine a cash-based wage economy with subsistence harvest and sharing of resources (Wheeler 1998, Kruse et al. 2008). Mixed economies can help balance the traditional values of native communities with the need to interface with the regional and national entities and a desire for access to their markets (Altman 2005). Remoteness and distance from major road systems, both of which characterize the Pribilofs, are associated with higher levels of subsistence activity in Alaskan villages (Wolfe and Walker 1987). However, generational decline in subsistence harvest or environmental changes can tilt the balance of the mixed economy toward a market economy and away from subsistence (Condon et al. 1995, Chabot 2003). In some communities, subsistence activity increases when resources are less available through other means, e.g. wages or social programs (Busilacchi et al. 2013). Subsistence may also be lower when the wage economy dominates because there is less time to participate heavily in both wage-earning and subsistence activity (Kerkvliet and Nebesky 1997). Thus changes in economics and cultural identity associated with modernization are likely to change the type and level of subsistence harvest in rural villages.

Apart from a state subsistence census, conducted in 1994, estimates of Pribilovian subsistence from the past 30 years focus almost entirely on marine mammal and groundfish, with little documentation of other forms of harvest (ADF\&G 1997, Fall et al. 2013). Over $80 \%$ of the islands' subsistence harvest comprises fur seal, feral reindeer, crab, and groundfish, with a few other marine mammals, e.g., walrus, seal, sea lion. Sea ducks, seabirds (adults and eggs), and berries make up a much lower relative proportion of the wild food diet (Fall et al. 2013). However, evidence suggests that seabird harvest played a larger role in traditional precontact Aleutian subsistence (Veltre and Veltre 1981). Historic and contemporary subsistence patterns differ, perhaps because of the history of cultural oppression and singlespecies focus on fur seals (Corbett and Swibold 2000). The islands are part of a large regional seabird monitoring program (Dragoo et al. 2014) and also the site of much research on seabird ecology and physiology (e.g., Hunt and Byrd 1999, Kitaysky et al. 2006, Byrd et al. 2008). This strong research and management focus has occurred largely without reference to the role of seabirds in the lives of the local communities. This study characterizes the relationships between the people of the Pribilofs and the seabird communities that nest on the sea cliffs.

We predicted that seabirds would be valued because of their role in Aleut and Pribilovian culture. However, because of general subsistence harvest decline in the Pribilofs (Scholz et al. 2007, Fall et al. 2013), we expected that seabird subsistence would be low because historically marine mammal harvest dominated the subsistence arena and fishing was the bulk of the remainder. In addition, Huntington et al. (2009) found a disconnect between society and the environment on the Pribilofs, partly because of reliance on outside inputs and declining use of natural resources. Declining involvement in the ecosystem may have also resulted in lowered interest or value placed on seabirds. We expected there to be a positive relationship between knowledge of seabirds, use of seabirds, and interest or value placed on seabirds; such knowledge can foster resilience by conserving knowledge of older resource use. This study conducted surveys and interviews to assess the current relationship between the people of St. Paul and
St. George, the two villages on the islands, and the seabirds. We were interested in people's attitudes toward seabirds, their subsistence use, potential economic roles of seabirds, and local knowledge of seabird biology and harvest.

\section{METHODS}

We conducted a survey and informal interviews of St. Paul and St. George residents to assess opinions toward seabirds and harvest levels. Our surveys and interviews took place in July and August of 2009. On each island, the lead researcher (R. C. Young on St. George, I. Dorresteijn on St. Paul) held a public meeting discussing our research and inviting the views of community members. Meetings were attended by approximately 15 to 20 people on each island. Attendance was lower on St. Paul, both absolutely and as a proportion of the population. Surveys were targeted at heads of households and were taken door-to-door as well as left in the village store, a place where it was likely to be encountered by almost every community member. Questionnaires were returned in person, so we were able to ensure that no household filled out more than one survey. Interview participants included: active harvesters, community leaders, elders, and any adult who wanted to contribute ideas or memories. Interviewees were selected by requests for interest at the meetings and during door-to-door surveying. In addition, we used snowball sampling methods (Bernard 2006). The goal of interviews was not to capture a representative sample of opinion or usage in the community, but to discover what knowledge and memories were held by those who use the resource most heavily.

The survey was a questionnaire with sections on seabird use and importance, knowledge of seabirds, importance of harvest, demographics, and bird identification and names. Questions employed a 5 point Likert scale, with 1 indicating "disagree," and 5, "agree." A demographic section collected information on ethnicity, gender, age, income, and time spent on the island annually. An open-ended set of questions on bird identification and names was included in the questionnaire, but because many respondents did not fill out this portion, we have excluded it from the analysis. Twenty-two surveys were collected on St. George and 31 on St. Paul. The 2010 census information lists St. George as having 41 households and St. Paul as having 162 households. Response rates were thus $53 \%$ and $19 \%$, respectively. The differences in response rate between the islands may be partly explained by the higher rate of people working outside the home on St. Paul, thus being unavailable for door-to-door surveys, and a faster pace of life resulting in less interest in surveys about a rarely used resource. This means that although opinions are fairly consistent, they may be biased toward interested parties, especially on St. Paul.

We conducted 15 informal interviews, 10 on St. Paul and 5 on St. George. More interviews were conducted on St. Paul, yet the interviews per household rate was twice as high on St. George, further demonstrating lower response rates on St. Paul. All interviews were conducted in person as unstructured discussions. Notes were taken by the interviewers, and were later compiled and compared qualitatively for major opinions, anecdotes, and illustrative quotes. Interviewers were R. C. Young and Sarah Youngren on St. George, and I. Dorresteijn and Thibaut Vergoz on St. Paul. 
Table 1. Demographic parameters. Census numbers are from the 2010 federal census, archived by the Alaska Department of Commerce, Community, and Economic Development at http://commerce.alaska.gov/cra/DCRAExternal/community, except for the "grew up on the Pribilofs" category, where they are from a 1994 Alaska Department of Fish and Game subsistence survey of households. Note, the 2010 census numbers reflect the entire population, whereas our numbers reflect only heads of households responding to our survey. The differences in whole population versus heads of households are particularly noticeable in age and gender categories.

\begin{tabular}{|c|c|c|c|c|c|c|c|}
\hline \multirow[b]{2}{*}{ Query } & \multirow[b]{2}{*}{ Category } & \multicolumn{3}{|c|}{ St. Paul } & \multicolumn{3}{|c|}{ St. George } \\
\hline & & Responses & Percent & Census & Responses & Percent & Census \\
\hline \multirow[t]{2}{*}{ Gender } & male & 24 & 80 & 53 & 16 & 73 & 58 \\
\hline & female & 6 & 20 & 47 & 6 & 27 & 42 \\
\hline \multirow[t]{2}{*}{ Ethnicity } & Aleut & 27 & 87 & 82 & 21 & 95 & 88 \\
\hline & non-Aleut & 4 & 13 & 18 & 1 & 5 & 12 \\
\hline Income & $<25 \mathrm{~K}$ & 4 & 13 & & 7 & 32 & \\
\hline \multirow[t]{4}{*}{ Level } & $25-50 \mathrm{~K}$ & 7 & 23 & & 7 & 32 & \\
\hline & $50-100 \mathrm{~K}$ & 11 & 35 & & 4 & 18 & \\
\hline & $100+\mathrm{K}$ & 4 & 13 & & 0 & 0 & \\
\hline & no response & 5 & 16 & & 4 & 18 & \\
\hline \multirow[t]{5}{*}{ Age } & $18-30 \mathrm{yrs}$ & 3 & 10 & 17 & 1 & 5 & 18 \\
\hline & $31-45$ yrs & 7 & 23 & 22 & 2 & 10 & 16 \\
\hline & $46-60 \mathrm{yrs}$ & 11 & 37 & 19 & 12 & 57 & 28 \\
\hline & $60+\mathrm{yrs}$ & 9 & 30 & 12 & 6 & 29 & 15 \\
\hline & no response & 1 & 3 & & 0 & 0 & \\
\hline \multirow[t]{3}{*}{ Origin } & grew up on Pribilofs & 27 & 87 & 60.6 & 20 & 91 & 68.3 \\
\hline & not on Pribilofs & 4 & 13 & & 0 & 0 & \\
\hline & no response & 0 & 0 & & 2 & 9 & \\
\hline
\end{tabular}

\section{RESULTS}

\section{Demographic results}

Demographic response parameters (Table 1) did not differ qualitatively from those in the Alaska Department of Fish and Game 1994 census of village demography and subsistence use (ADF\&G 1997).

\section{Seabird importance}

Nearly all survey respondents agreed that seabirds are important to Pribilof culture and Aleut culture (Table 2). On St. Paul, only two people disagreed with the statement, "Seabirds are important to Pribilovian culture," and the same two also disagreed with the statement, "Seabirds are important to Aleut culture." Overall, there was a decline from the general to the specific: there was near universal agreement that seabirds were important to Pribilovian and Aleut culture, but only $71 \%$ agreed that seabirds were important to them personally. Seabirds were used by about a third of the households, and most respondents agreed that they are important to the subsistence economy of the islands. In addition, personal importance was rated higher by men than by women (males' mean Likert response: $4.2 \pm 0.2$, females': $2.9 \pm 0.6$; $\mathrm{t}$ $=-2.23$, df $=12, \mathrm{p}=0.045$ ). Ethnicity (Aleut/non-Aleut) and income level were not significant (all $\mathrm{p}>0.57$ ). Age was not a significant predictor of personal seabird interest $\left(\mathrm{F}_{3,47}=1.77, \mathrm{p}\right.$ $=0.16$ ), but those in the 18-30 year-old age group were much less likely to consider seabirds personally important than other age groups (Fig. 2). Several older interviewees on both islands reflected on the lack of importance of seabirds to younger community members. They expressed a desire for young people to participate more in the seabird harvests with their elders and a concern that the resource is not being harvested, and thus not shared within the community.
Fig. 2. Importance of seabirds by age of respondent. Seabirds were consistently marked as more important by older members of the community.

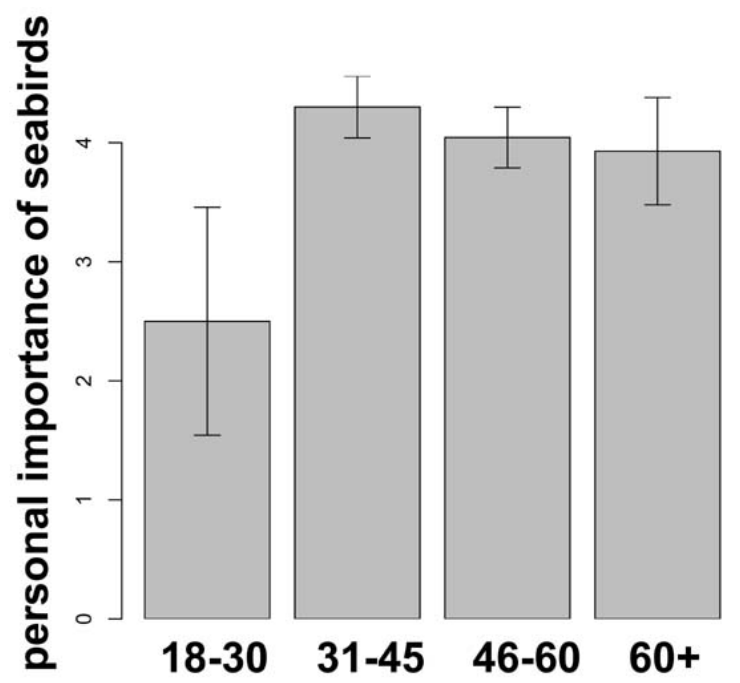

Interviews demonstrated that seabird observations and harvesting had been an important part of family life and growing up. Several interviewees remembered harvesting Least Auklets (Aethia pusilla) as children and described it as a good way to get children involved in subsistence activities and helping provide for the family. Joining the adult seabird hunt was described as a rite of passage, with one interviewee remembering fondly the gift of "a ten-gauge at ten" so that he could help his father hunt sea ducks and kittiwakes. Others remembered the teachings of parents and 
Table 2. Survey responses to questions about the importance of seabirds. For each island the sample size (n) responding to each question is given, along with the responses broken down according to the Likert scale: $1=$ Disagree; $2=$ Somewhat Disagree; $3=$ Neither; $4=$ Somewhat Agree; and $5=$ Agree. For each statement the percent of responses agreeing and disagreeing is provided for each community. The last column indicates the percentage of responses in agreement with the statement in the entire sample.

\begin{tabular}{|c|c|c|c|c|c|c|c|c|c|c|c|c|c|c|c|c|c|}
\hline \multirow{2}{*}{$\begin{array}{l}\text { Seabird Importance } \\
\text { Statement }\end{array}$} & \multicolumn{8}{|c|}{ St. Paul } & \multicolumn{8}{|c|}{ St. George } & \multirow{2}{*}{$\begin{array}{c}\text { Both } \\
\text { Agree }(\%)\end{array}$} \\
\hline & $\mathrm{n}$ & 1 & 2 & 3 & 4 & 5 & $\begin{array}{c}\text { Disagree } \\
(\%)\end{array}$ & $\begin{array}{c}\text { Agree } \\
(\%)\end{array}$ & $\mathrm{n}$ & 1 & 2 & 3 & 4 & 5 & $\begin{array}{c}\text { Disagree } \\
(\%)\end{array}$ & Agree $(\%)$ & \\
\hline $\begin{array}{l}\text { Seabirds are } \\
\text { important to } \\
\text { Priblovian culture. }\end{array}$ & 30 & 2 & 0 & 0 & 3 & 25 & $7 \%$ & $93 \%$ & 22 & 0 & 0 & 0 & 3 & 19 & $0 \%$ & $100 \%$ & $96 \%$ \\
\hline $\begin{array}{l}\text { Seabirds are } \\
\text { important to Aleut } \\
\text { culture. }\end{array}$ & 31 & 2 & 0 & 0 & 3 & 26 & $6 \%$ & $94 \%$ & 22 & 1 & 0 & 0 & 4 & 17 & $5 \%$ & $95 \%$ & $94 \%$ \\
\hline $\begin{array}{l}\text { Seabirds are } \\
\text { important to me } \\
\text { personally. }\end{array}$ & 31 & 6 & 0 & 3 & 7 & 15 & $19 \%$ & $71 \%$ & 21 & 1 & 0 & 5 & 3 & 12 & $5 \%$ & $71 \%$ & $71 \%$ \\
\hline $\begin{array}{l}\text { Seabirds are } \\
\text { important to the } \\
\text { Priblovian economy. }\end{array}$ & 30 & 3 & 0 & 7 & 9 & 11 & $10 \%$ & $67 \%$ & 21 & 4 & 0 & 2 & 3 & 12 & $19 \%$ & $71 \%$ & $69 \%$ \\
\hline $\begin{array}{l}\text { My household relies } \\
\text { on seabird } \\
\text { subsistence. }\end{array}$ & 31 & 9 & 4 & 7 & 8 & 3 & $42 \%$ & $35 \%$ & 20 & 7 & 0 & 7 & 1 & 5 & $35 \%$ & $30 \%$ & $33 \%$ \\
\hline
\end{tabular}

elders when describing hunting practices and reminiscing about their early experiences.

Seabird subsistence was also remembered as part of the Aleut identity. When the Pribilofs were still managed as an independent or government-controlled seal harvesting business, or what an interviewee described as "the government days," seabirds were a primary source of protein to the Aleut population. Off-island groceries were not routinely available to the nonwhite population of the island. One interviewee described the Red-faced Cormorant (Phalacrocorax urile) as "the Aleut turkey," because only white officials were allowed a turkey at Thanksgiving.

\section{Current seabird use}

The results for questions aimed at describing current seabird use (Table 3) mirrored the results for seabird importance: most respondents agreed that seabirds should be harvested, indicating support for seabird use and importance in the abstract. However, less than half of respondents indicated that they prefer to consume seabird protein over other sources of locally available food, which included store food or alternative subsistence sources such as seals, fish, or sea ducks. Subsistence seabird use increased with age: in the lowest age category ( 18 to $30 \mathrm{yrs}$ old ), $0 \%$ indicated household use; use jumped to $30 \%$ of respondents aged 31 to 45 yrs, $36 \%$ of those 46 to $60 \mathrm{yrs}$ old, and $43 \%$ of those over 60 . In addition, on both islands there was a roughly even split between respondents agreeing with the statement, "I prefer to eat seabird meat to other forms of protein," and those agreeing with, "I only eat seabird products when there is nothing else." However, on both islands, slightly more respondents agreed with the "last resort" option than with that for "preference." This was especially notable in the age group 45 to 60 , where $33 \%$ said they preferred seabird meat, and $48 \%$ said they would eat it only as a last resort. However, these results should be interpreted cautiously because 8 respondents (16\% of total surveys) somewhat agreed or agreed with both the "last resort" and the "preference" statements. Most interviewees said they preferred food from the store to seabird meat, and that bird harvesting was most important in the past, when there was no store, or for large families who needed the meat to augment their diets.

\section{Seabird knowledge}

Seabird knowledge was strongly positively related to personal importance of seabirds $(\mathrm{t}=5.19$, df $=49, \mathrm{p}<0.0001$; Table 4). Those who agreed with the statement, "I know a lot about the seabirds of these islands," also agreed that, "Seabirds are important to me personally." It is impossible to determine causality in this relationship; those who know more about seabirds may find them more important, or those who find seabirds important may be motivated to seek out knowledge about them. On both islands, $50-60 \%$ of respondents believe that current harvest regulations are appropriate, and this supports our interview findings where people described harvest levels as low and never complained that regulations were a constraint on seabird harvest activities. However, on each island there was a roughly even split between those indicating harvest regulations were adequate and those indicating they should be changed. No suggestions of changes were made for seabird harvest regulations, perhaps indicating that change is desired in nonseabird subsistence regulations instead. This confusion was reflected in interviews as well; some interviewees told researchers, "There are no rules" for harvest, while others said the rules were good, because they prevented overharvesting.

Questions aimed at eliciting respondents' knowledge of seabirds and their own evaluation of that knowledge, i.e., did they consider themselves knowledgeable about seabirds and did they wish to know more, also provided the first real differences between the islands. Residents of the two islands differed in their perception of their own seabird knowledge. On St. Paul, about 60\% agreed that they knew a lot about seabirds and would like to know more, and about $18 \%$ disagreed with those statements. On St. George, 
Table 3. Survey responses to statements assessing current seabird use and preferences. For each island the sample size (n) responding to each question is given, along with the responses broken down according to the Likert scale: $1=$ Disagree; $2=$ Somewhat Disagree; $3=$ Neither; $4=$ Somewhat Agree; and $5=$ Agree. The last statement was not done on the Likert agreement scale: A $=2+$ times/week; $\mathrm{B}=2+$ times/month; $\mathrm{C}=2+$ times/year; $\mathrm{D}=$ never. For each statement the percent of responses agreeing and disagreeing (or visiting often and rarely) is provided for each community. The last column indicates the percentage of responses in agreement with the statement in the entire sample.

\begin{tabular}{|c|c|c|c|c|c|c|c|c|c|c|c|c|c|c|c|c|c|}
\hline \multirow{2}{*}{$\begin{array}{l}\text { Current Seabird } \\
\text { Use } \\
\text { Statement }\end{array}$} & \multicolumn{8}{|c|}{ St. Paul } & \multicolumn{8}{|c|}{ St. George } & \multirow{2}{*}{$\begin{array}{c}\text { Both } \\
\text { Agree (\%) }\end{array}$} \\
\hline & $\mathrm{n}$ & 1 & 2 & 3 & 4 & 5 & Disagree (\%) & $\begin{array}{c}\text { Agree } \\
(\%)\end{array}$ & $\mathrm{n}$ & 1 & 2 & 3 & 4 & 5 & Disagree (\%) & $\begin{array}{c}\text { Agree } \\
(\%)\end{array}$ & \\
\hline $\begin{array}{l}\text { Seabirds should } \\
\text { be harvested. }\end{array}$ & 29 & 3 & 4 & 2 & 6 & 14 & $24 \%$ & $69 \%$ & 21 & 1 & 2 & 1 & 4 & 13 & $14 \%$ & $81 \%$ & $74 \%$ \\
\hline $\begin{array}{l}\text { I prefer to eat } \\
\text { seabird meat to } \\
\text { other forms of } \\
\text { protein. }\end{array}$ & 30 & 7 & 4 & 6 & 8 & 5 & $37 \%$ & $43 \%$ & 21 & 5 & 3 & 6 & 1 & 6 & $38 \%$ & $33 \%$ & $39 \%$ \\
\hline $\begin{array}{l}\text { I only eat seabird } \\
\text { products when } \\
\text { there is nothing } \\
\text { else. }\end{array}$ & 29 & 9 & 1 & 5 & 7 & 7 & $34 \%$ & $48 \%$ & 21 & 9 & 0 & 4 & 4 & 4 & $43 \%$ & $38 \%$ & $44 \%$ \\
\hline $\begin{array}{l}\text { My household } \\
\text { relies on seabird } \\
\text { subsistence. }\end{array}$ & 31 & 9 & 4 & 7 & 8 & 3 & $42 \%$ & $35 \%$ & 20 & 7 & 0 & 7 & 1 & 5 & $35 \%$ & $30 \%$ & $33 \%$ \\
\hline Statement & $\mathrm{n}$ & A & B & $\mathrm{C}$ & $\mathrm{D}$ & - & Often & Rarely & $\mathrm{n}$ & A & B & $\mathrm{C}$ & $\mathrm{D}$ & - & Often & Rarely & Often \\
\hline $\begin{array}{l}\text { How often do } \\
\text { you go to the } \\
\text { seabird cliffs/ } \\
\text { colonies? }\end{array}$ & 31 & 2 & 4 & 21 & 4 & - & $19 \%$ & $81 \%$ & 13 & 1 & 3 & 4 & 5 & - & $31 \%$ & $69 \%$ & $23 \%$ \\
\hline
\end{tabular}

agreement was higher: $75 \%$ agreed that they knew a lot about seabirds, and $90 \%$ would like to know more. No one indicated disagreement; the remaining responses indicated neutrality. Although percentages reporting use of seabird harvest were comparable (35\% on St. Paul, $30 \%$ on St. George), St. George residents appear more interested in seabird knowledge than St. Paul residents.

Interviews provided a great deal of harvest-related knowledge, because interviewees were active harvesters, elders who remembered days of more harvesting in the past, or people interested in our project. The most commonly harvested birds were the Black- and Red-legged Kittiwakes (Rissa tridactyla and $R$. brevirostris), the Common and Thick-billed Murre (Uria aalge and $U$. lomvia; eggs and adults), and the Least Auklet. Interviews suggest that Red-legged Kittiwakes were more desired than Blacklegged. Interviewees preferred to harvest kittiwakes because they fledge or they first arrive to the breeding colony in the early summer. Recently arrived birds were described as less "fishytasting." Another manifestation of this preference was to hunt adults before eggs are laid, early in the breeding season.

Hunting techniques varied by species. One interviewee told us kittiwakes were shot over the water and blown back to land. Least Auklets were usually described as being hunted with nets or sticks thrown into low-flying flocks. Some interviewees described Least Auklets as being too much trouble to harvest these days or only worth it so children can practice.

\section{Economic outlook}

Our surveys also explored perceptions of economic conditions and tourism (Table 5). Economic outlook was assessed as equally poor on both islands. In both communities the per capita or household income estimate is not different from the Alaskan poverty level (Alaska Department of Commerce, Community, and Economic Development at http://commerce.alaska.gov/cra/ DCRAExternal/community). Overall $88 \%$ of respondents said the economic situation on the Pribilofs was getting worse, whereas only $10 \%$ felt it was improving. This outlook did not differ between the islands. One interviewee said that seabird harvest was tied to the economy, with more harvesting occurring when there is less money available in the cash economy. Tourism was regarded favorably, with $87 \%$ believing it to be important to the economy of the islands. To our binary set of questions (there is too much tourism/there is not enough tourism) responses indicated $73 \%$ disagreement that there is too much tourism and $81 \%$ agreement that there is not enough, indicating consistent high levels of support for increasing tourism. Several interviews also indicated interest in expanding tourism, involving locals as guides, or collaborating to share knowledge with scientists. One interviewee described expanded tour guide opportunities positively saying people would, "be really into that." Others expressed interest in a children's summer camp that could enable kids to learn about seabirds.

\section{DISCUSSION}

We found overwhelming support for the importance of seabirds as a cultural resource to the Aleuts, to the people of the Pribilofs, 
Table 4. Survey responses to statements assessing knowledge of seabird biology and harvest regulations. For each island the sample size $(\mathrm{n})$ responding to each question is given, along with the responses broken down according to the Likert scale: $1=$ Disagree; $2=$ Somewhat Disagree; 3 = Neither; 4 = Somewhat Agree; and $5=$ Agree. For each statement the percent of responses agreeing and disagreeing is provided for each community. The last column indicates the percentage of responses in agreement with the statement in the entire sample.

\begin{tabular}{|c|c|c|c|c|c|c|c|c|c|c|c|c|c|c|c|c|c|}
\hline \multirow{2}{*}{$\begin{array}{l}\text { Seabird } \\
\text { Knowledge } \\
\text { Statement } \\
\end{array}$} & \multicolumn{8}{|c|}{ St. Paul } & \multicolumn{8}{|c|}{ St. George } & \multirow{2}{*}{$\begin{array}{c}\text { Both } \\
\text { Agree (\%) }\end{array}$} \\
\hline & $\mathrm{n}$ & 1 & 2 & 3 & 4 & 5 & Disagree $(\%)$ & Agree $(\%)$ & $\mathrm{n}$ & 1 & 2 & 3 & 4 & 5 & Disagree $(\%)$ & Agree $(\%)$ & \\
\hline $\begin{array}{l}\text { Current harvest } \\
\text { regulations are } \\
\text { appropriate. }\end{array}$ & 27 & 3 & 2 & 5 & 9 & 8 & $19 \%$ & $63 \%$ & 18 & 1 & 1 & 6 & 1 & 9 & $11 \%$ & $56 \%$ & $60 \%$ \\
\hline $\begin{array}{l}\text { Current harvest } \\
\text { regulations } \\
\text { should be } \\
\text { changed. }\end{array}$ & 27 & 4 & 3 & 9 & 5 & 6 & $26 \%$ & $41 \%$ & 18 & 8 & 1 & 6 & 1 & 2 & $50 \%$ & $17 \%$ & $31 \%$ \\
\hline $\begin{array}{l}\text { I know a lot } \\
\text { about the } \\
\text { seabirds of these } \\
\text { islands. }\end{array}$ & 31 & 3 & 3 & 6 & 11 & 8 & $19 \%$ & $61 \%$ & 20 & 0 & 0 & 5 & 8 & 7 & $0 \%$ & $75 \%$ & $67 \%$ \\
\hline $\begin{array}{l}\text { I would like to } \\
\text { know more about } \\
\text { seabirds. }\end{array}$ & 30 & 4 & 1 & 6 & 9 & 10 & $17 \%$ & $63 \%$ & 20 & 0 & 0 & 2 & 4 & 14 & $0 \%$ & $90 \%$ & $74 \%$ \\
\hline $\begin{array}{l}\text { Seabirds are } \\
\text { important to me } \\
\text { personally. }\end{array}$ & 31 & 6 & 0 & 3 & 7 & 15 & $19 \%$ & $71 \%$ & 21 & 1 & 0 & 5 & 3 & 12 & $5 \%$ & $71 \%$ & $71 \%$ \\
\hline $\begin{array}{l}\text { Some kinds of } \\
\text { seabird are doing } \\
\text { better than } \\
\text { others. }\end{array}$ & 29 & 3 & 2 & 8 & 4 & 12 & $17 \%$ & $55 \%$ & 19 & 2 & 1 & 4 & 7 & 5 & $16 \%$ & $63 \%$ & $58 \%$ \\
\hline
\end{tabular}

and to most respondents personally. The strongest aspect of this importance was the way seabird usage had been a family experience and value. All memories of seabird harvesting were of family learning, coming of age, and ways in which children were taught to be valuable members of the community. For example, Least Auklet hunting was a way for children to contribute protein to the family, learn traditional harvesting techniques, and bond socially with family and community members (Orbach and Holmes 1983; personal observation). However, the disconnect between values and practice found by Huntington et al. (2009) still stands. Few people responded that they continue to harvest and use seabirds for subsistence harvest. When asked about seabird subsistence in general, the discussion always quickly turned to memories of hunts and harvests, but in most surveys and interviews they were just that: memories. Younger householders do not harvest at the same levels as older householders, indicating that the young families are not building these same memories of seabird harvest and the importance of them as a resource. Thus in the future, the knowledge and experience of seabird biology and subsistence will likely continue to decline, further weakening a system that is already disconnected.

Therefore, why is harvest low when interest in the resource and claims of knowledge are high? Our results indicate that this disconnect is driven economically and socially. According to interviewees, seabird subsistence has declined because it was supplanted by the increased availability and ease of store-food access. The food from the store is easy to obtain, requiring little effort and only cash as a tool to acquire it. However, subsistence harvest of fish, reindeer, and fur seals continues, so store food availability alone does not explain the decline in seabird harvesting. For subsistence harvest, seabirds appear to be less valued than the other species where harvest has been maintained. Several interview respondents indicated that seabird subsistence is preferred when economic times are hard, which was also reported in a previous study (Scholz et al. 2007) on St. George as well, and has been seen in other communities (Busilacchi et al. 2013). In other coastal Alaskan communities harvest of murre and gull eggs is very low $(\sim 4 \%)$ but increasing, potentially related to environmental and economic changes (Fall et al. 2013). On St. Paul, seabird subsistence is more often undertaken for cultural rather than nutritional or economic reasons, a pattern seen in other communities as well (Merkel 2010). Socially, although interest in seabirds is high, reductions in the number of households participating in seabird subsistence mean that fewer children are learning how to harvest as they grow up, another common pattern in modernizing northern communities (Moerlein and Carothers 2012). We found few people who claimed to prefer seabird food, although elders expressed a desire for sharing in the harvest. Despite the lack of current usage, survey results expressed knowledge of seabirds and a desire to learn more. The presence of current knowledge was also supported in the interviews, where comprehensive information on when and how to harvest seabirds was revealed.

Only about a third of survey respondents used seabird subsistence at all. Rates of harvest are likely much lower than rates of use 
Table 5. Survey responses to statements assessing perceptions of economic conditions and tourism. For each island the sample size (n) responding to each question is given, along with the responses broken down according to the Likert scale: $1=$ Disagree; $2=$ Somewhat Disagree; 3 = Neither; 4 = Somewhat Agree; and 5 = Agree. The last statement was not done on the Likert agreement scale: $\mathrm{A}=$ worse; $\mathrm{B}=$ stable; and $\mathrm{C}=$ improving. For each statement the percent of responses agreeing and disagreeing (or claiming worse vs. improving) is provided for each community. The last column indicates the percentage of responses in agreement with the statement in the entire sample. For the last statement, it indicates those who felt the economy was getting worse.

\begin{tabular}{|c|c|c|c|c|c|c|c|c|c|c|c|c|c|c|c|c|c|}
\hline \multirow{2}{*}{$\begin{array}{l}\text { Economic } \\
\text { Outlook } \\
\text { Statement }\end{array}$} & \multicolumn{8}{|c|}{ St. Paul } & \multicolumn{8}{|c|}{ St. George } & \multirow{2}{*}{$\begin{array}{c}\text { Both } \\
\text { Agree (\%) }\end{array}$} \\
\hline & $\mathrm{n}$ & 1 & 2 & 3 & 4 & 5 & $\begin{array}{c}\text { Disagree } \\
(\%)\end{array}$ & $\begin{array}{c}\text { Agree } \\
(\%)\end{array}$ & $\mathrm{n}$ & 1 & 2 & 3 & 4 & 5 & $\begin{array}{c}\text { Disagree } \\
(\%)\end{array}$ & $\begin{array}{c}\text { Agree } \\
(\%)\end{array}$ & \\
\hline $\begin{array}{l}\text { Tourism is } \\
\text { important to the } \\
\text { Priblovian } \\
\text { economy. }\end{array}$ & 31 & 2 & 1 & 1 & 7 & 20 & $10 \%$ & $87 \%$ & 21 & 2 & 0 & 1 & 3 & 15 & $10 \%$ & $86 \%$ & $87 \%$ \\
\hline $\begin{array}{l}\text { There is too much } \\
\text { tourism on the } \\
\text { Pribilofs. }\end{array}$ & 31 & 15 & 8 & 6 & 2 & 0 & $74 \%$ & $6 \%$ & 21 & 11 & 4 & 4 & 1 & 1 & $71 \%$ & $10 \%$ & $8 \%$ \\
\hline $\begin{array}{l}\text { There is not } \\
\text { enough tourism } \\
\text { on the Pribilofs. }\end{array}$ & 31 & 1 & 3 & 3 & 4 & 20 & $13 \%$ & $77 \%$ & 22 & 0 & 1 & 2 & 4 & 15 & $5 \%$ & $86 \%$ & $81 \%$ \\
\hline Statement & $\mathrm{n}$ & $\mathrm{A}$ & $\mathrm{B}$ & $\mathrm{C}$ & - & - & Worse & Better & $\mathrm{n}$ & $\mathrm{A}$ & $\mathrm{B}$ & $\mathrm{C}$ & - & - & Worse & Better & Worse \\
\hline $\begin{array}{l}\text { Is the economic } \\
\text { situation on the } \\
\text { Pribilofs } \\
\text { improving or } \\
\text { getting worse? }\end{array}$ & 28 & 25 & 0 & 3 & - & - & $89 \%$ & $11 \%$ & 20 & 17 & 1 & 2 & - & - & $85 \%$ & $10 \%$ & $88 \%$ \\
\hline
\end{tabular}

because resources are often shared with households that may not participate in harvest. Seabird use levels increased with age, demonstrating that the younger generations may lack the knowledge or desire to continue traditional harvesting or diet patterns. The positive relationships between knowledge of seabirds and importance, and between importance of seabirds and age of respondent indicate a pattern of generational change. A lack of knowledge and importance among younger householders indicates a break in the links of knowledge transfer. The connection between knowledge of a subject and importance placed upon it leads to weakening ties between people and the resources as knowledge fades; seabirds will be less important to future generations who do not use them for subsistence and have not been taught their cultural importance. Removal of these knowledge and experiential connections may weaken a socialecological system, removing potential fallback options, and in turn lowering adaptive capacity, decreasing resilience. This is true whether personal importance drives increased knowledge, or vice versa. In fact, it is likely that seabirds are more important to those who have been taught about them and also that those who consider seabirds important have learned more about them.

The rekindling of interest and knowledge via increased harvest or education could be an important way to strengthen the socialecological system in the Pribilof Islands. Retention of knowledge about previous harvest patterns or new uses of subsistence resources can provide fodder for adaptation to new conditions, making the communities resilient to abandonment. Interest was expressed in children's camps that teach seabird biology and ecology. This could provide a cultural role for seabirds that fosters knowledge in the next generation, even if seabird subsistence remains low. An interest in the local environment and traditional ways of life that tie social systems to ecosystems will foster the strong community ties that help preserve remote communities (Blanchard 1999). It is also a source of the adaptive capacity that provides the means for self-preservation. Trends toward modernization make it unlikely that a culture relying heavily on seabird subsistence for calories will return; but that does not mean seabirds do not have economic and cultural potential for the Pribilof Island communities.

Although the economic outlook was largely perceived as grim, most interviews also mentioned the economic contribution of subsistence harvest and the need for more economic opportunities on the islands. These findings are also consistent with previous research: subsistence is declining and economic outlook is poor (Huntington et al. 2009). Interest in expanding tourism as an economic opportunity was expressed in interviews, and has been previously suggested in the literature (Young 1987, Sherwonit 1994). Tourism development could benefit the local economy and increase ties to the seabird resource without affecting current subsistence patterns. However, such development would face large hurdles. The islands are remote, and currently the infrastructure does not exist to support tourists, who would likely invest large sums on travel. Challenges due to unpredictable weather are common in polar tourism development (Stewart et al. 2007) and would also need to be addressed in the Pribilofs, where weather delays are not uncommon and create uncertain access to the islands during the spring and summer, when seabirds are at the islands for breeding. These are the same months that allow viewing of wildflowers and marine mammals, as well as when snow is absent, providing access to most of the islands. Last, if 
seabirds become an ecotourism draw, community members would need to participate in the development of guide skills and infrastructure to increase tourism opportunities for locals and outside tourists. Tourism is often seen in remote areas as a way to develop the local economy while also re-engaging youth with their own culture and traditions of land use (Chanteloup 2013). Interviewees responded positively to questions about developing the base of knowledge that would support an ecotourism industry and also offered their own suggestions: for a summer camp that teaches children about local seabirds or for opportunities to share their own seabird knowledge with researchers while learning about the seabirds from scientists' perspectives as well. Some collaboration and exchange has already begun with the founding and expansion of the Seabird Youth Network (http://www. seabirdyouth.org/). But in the end, any development of such an industry will need strong community support (Notzke 1999), which may be in development (Merculieff 1995), but was not strongly in evidence during our fieldwork in 2009.

In conclusion, seabirds are an important cultural resource on the Pribilofs. Seabird hunting is more often undertaken for cultural rather than nutritional reasons, but is declining in both islands. If future generations are not taught to appreciate seabirds via subsistence participation or education efforts, this link will likely be lost. The rekindling of interest and knowledge via increased harvest or education could be an important way to strengthen the social-ecological system in the Pribilof Islands, and provide a baseline of interest and knowledge to fuel potential tourism expansion.

\section{Responses to this article can be read online at: http://www.ecologyandsociety.org/issues/responses. $\mathrm{php} / 7158$}

\section{Acknowledgments:}

We would like to thank the hard-working crews of the BESTBSIERP teams in 2009, especially Thibaut Vergoz and Sarah Youngren. Thanks are also due to the communities of St. Paul and St. George for participating in our research, attending our presentations, and contributing their time, effort, and interest. The research for this paper was supported by North Pacific Research Board (including projects B65 and B77) and National Science Foundation grant "IGERT: Global-Local Interactions: Resilience and Adaption of Social-Ecological Systems in a Rapidly Changing North" (Grant \# 0654441). The views expressed in the paper are those of the authors and do not represent the National Science Foundation or other agencies.

\section{LITERATURE CITED}

Alaska Department of Fish and Game (ADF\&G). 1997. Overview of information about subsistence uses of marine mammals in Aleutian/Pribilof Islands communities. Division of Subsistence, Alaska Department of Fish and Game, Anchorage, Alaska, USA.

Altman, J. 2005. Economic futures on Aboriginal land in remote and very remote Australia: hybrid economies and joint ventures. Pages 121-134 in D. Austin-Broos and G. Macdonald, editors.
Aborigines, culture, and economy: the past, present, and future of rural and remote indigenous lives. University of Sydney Press, Sydney, Australia.

Berardi, G. 1998. Natural resource policies, unforgiving geographies, and persistent poverty in Alaska Native villages. Natural Resources Journal 38(1):85-108.

Berman, M., C. Nicolson, G. P. Kofinas, J. Tetlichi, and S. Martin. 2004. Adaptation and sustainability in a small Arctic community: results of an agent-based simulation model. Arctic 57(4):401-414. http://dx.doi.org/10.14430/arctic517

Bernard, H. R. 2006. Research methods in anthropology. AltaMira, Lanham, Maryland, USA.

Blanchard, K. A. 1999. Culture and conservation: restoring seabird populations on the North Shore of the Gulf of St. Lawrence Society for Conservation Biology Newsletter 6(4).

Busilacchi, S., G. R. Russ, A. J. Williams, S. G. Sutton, and G. A. Begg. 2013. The role of subsistence fishing in the hybrid economy of an indigenous community. Marine Policy 37:183-191. http:// dx.doi.org/10.1016/j.marpol.2012.04.017

Byrd, G. V., J. A. Schmutz, and H. M. Renner. 2008. Contrasting population trends of piscivorous seabirds in the Pribilof Islands: a 30-year perspective. Deep Sea Research Part II 55 (16-17):1846-1855. http://dx.doi.org/10.1016/j.dsr2.2008.04.004

Chabot, M. 2003. Economic changes, household strategies, and social relations of contemporary Nunavik Inuit. Polar Record 39:19-34. http://dx.doi.org/10.1017/S0032247402002711

Chanteloup, L. 2013. Wildlife as a tourism resource in Nunavut. Polar Record 49:240-248. http://dx.doi.org/10.1017/S0032247412000617

Condon, R. G., P. Collings, and G. Wenzel. 1995. The best part of life: subsistence hunting, ethnicity, and economic adaptation among young adult Inuit males. Arctic 48(1):31-46. http://dx.doi. org/10.14430/arctic1222

Corbett, H. D., and S. M. Swibold. 2000. The Aleuts of the Pribilof Islands, Alaska. In M. M. R. Freeman, editor. Endangered people of the Arctic. Struggle to survive. Greenwood Press, Westport, Connecticut, USA. [online] URL: http://www. amiq.org/aleuts.html

Dragoo, D. E., H. M. Renner, and D. B. Irons. 2014. Breeding status and population trends of seabirds in Alaska, 2013. U.S. Fish and Wildlife Service, Alaska Maritime National Wildlife Refuge 2014/03, Homer, Alaska, USA.

Dryzek, J., and O. R. Young. 1985. Internal colonialism in the Circumpolar North: the case of Alaska. Development and Change 16(1):123-145. http://dx.doi.org/10.1111/j.1467-7660.1985.tb00204. $\underline{\mathrm{X}}$

Fall, J. A., N. S. Braem, C. L. Brown, L. B. HutchinsonScarbrough, D. S. Koster, and T. M. Krieg. 2013. Continuity and change in subsistence harvests in five Bering Sea communities: Akutan, Emmonak, Savoonga, St. Paul, and Togiak. Deep Sea Research Part II 94:274-291. http://dx.doi.org/10.1016/j. dsr2.2013.03.010

Hay, J. E. 2013. Small island developing states: coastal systems, global change and sustainability. Sustainability Science 8:309-326. http://dx.doi.org/10.1007/s11625-013-0214-8 
Hunt, G. L., and G. V. Byrd. 1999. Marine bird populations and carrying capacity of the Eastern Bering Sea. Pages 631-650 in T. R. Loughlin and K. Ohtani, editors. Dynamics of the Bering Sea. University of Alaska, Fairbanks, Alaska, USA.

Huntington, H. P., S. A. Kruse, and A. J. Scholz. 2009. Demographic and environmental conditions are uncoupled in the social-ecological system of the Pribilof Islands. Polar Research 28:119-128. http://dx.doi.org/10.1111/j.1751-8369.2009.00096.x

Jones, D. K. 1980. A century of servitude: Pribilof Aleuts under $U$. S. Rule. University Press of America, Washington, D.C., USA.

Kerkvliet, J., and W. Nebesky. 1997. Whaling and wages on Alaska's North Slope: a time allocation approach to natural resource use. Economic Development and Cultural Change 45 (3):651-665. http://dx.doi.org/10.1086/452295

Kitaysky, A. S., E. V. Kitaiskaia, J. F. Piatt, and J. C. Wingfield. 2006. A mechanistic link between chick diet and decline in seabirds? Proceedings of the Royal Society B 273:445-450. http:// dx.doi.org/10.1098/rspb.2005.3351

Kruse, J. A., B. Poppel, L. Abryutina, G. Duhaime, S. Martin, M. Poppel, M. Kruse, E. Ward, P. Cochran, and V. Hanna. 2008. Survey of living conditions in the Arctic (SliCA). Pages 107-134 in V. Møller, D. Huschka and A. C. Michalos, editors. Barometers of quality of life around the globe: How are we doing? Social Indicators Research Series 33. Springer, Dordrecht, The Netherlands. http://dx.doi.org/10.1007/978-1-4020-8686-1 5

Merculieff, L. 1995. The key to conflict resolution: reconnection with the sacred; the Pribilof Aleut case study. Culture, Resources and Conflicts(19.3):61-63.

Merkel, F. R. 2010. Seabird harvest, indicator \#19. Pages 89-91 in Arctic biodiversity trends 2010: selected indicators of change. CAFF International Secretariat, Akureyri, Iceland.

Moerlein, K. J., and C. Carothers. 2012. Total environment of change: impacts of climate change and social transitions on subsistence fisheries in Northwest Alaska. Ecology and Society 17(1): 10. http://dx.doi.org/10.5751/ES-04543-170110

Notzke, C. 1999. Indigenous tourism development in the Arctic. Annals of Tourism Research 26(1):55-76. http://dx.doi. org/10.1016/S0160-7383(98)00047-4

Orbach, M. K., and B. Holmes. 1983. Aleuts of the Seal Islands. Department of Sociology, Anthropology and Economics, East Carolina University, Greenville, North Carolina, USA.

Scholz, A. J., S. A. Kruse, H. Huntington, R. S. P. Lewis, S. Klain, and J. Ahmann. 2007. Socioeconomic baseline information for the Pribilof Islands. Project 528. North Pacific Research Board, Anchorage, Alaska, USA.

Sherwonit, B. 1994. Taking back the Pribilofs. Alaska September:24-31.

Stewart, E. J., S. E. L. Howell, D. Draper, J. Yackel, and A. Tivy. 2007. Sea ice in Canada's Arctic: implications for cruise tourism. Arctic 60(4):370-380.

Veltre, D. W., and M. J. Veltre. 1981. A preliminary baseline study of subsistence resource utilization in the Pribilof Islands. Technical Paper \# 57. Division of Subsistence, Alaska
Department of Fish and Game, Juneau, Alaska, USA.

Wheeler, P. C. 1998. The role of cash in northern economies: a case study of four Alaskan Athabascan villages. Dissertation. University of Alberta, Edmonton, Alberta, Canada.

Wolfe, R. J., and R. J. Walker. 1987. Subsistence economies in Alaska: productivity, geography, and development impacts. Arctic Anthropology 24(2):56-81.

Young, O. R. 1987. The Pribilof Islands: a view from the periphery. Anthropologica 29:149-167. http://dx.doi.org/10.2307/25605228 